\title{
Tata Artistik (Scenografi) dalam Pertunjukan Kesenian Tradisi Berbasis Kerakyatan
}

\author{
Heny Purnomo \\ Sekolah Tinggi Kesenian Wilwatikta Surabaya \\ henimensystem@gmail.com
}

\begin{abstract}
Abstrak
Kepuasan rasa dan nilai estetik yang didapatkan penonton melalui interaksi dalam pertunjukan sering menjadi persoalan yang berujung pada merosotnya aktivitas produksi pergelaran. Beberapa dekade terakhir, ludruk sebagai pertunjukan tradisi berbasis kerakyatan, kini tampak sepi penonton, dan persoalan yang mendasar ketika pertunjukan Irama Budaya sebagai satu-satunya ludruk tobong yang bertahan di Surabaya belum mampu menarik perhatian penonton. Pertunjukan yang diadakan secara live di Gedung Ludruk THR Surabaya, kini bertambah beban permasalahannya ketika media televisi berkembang dan meningkat sangat pesat. Berbagai tayangan hiburan berbasis industri seni popular, sekarang didukung panataan artistik dengan kecanggihan teknologi, namun juga memunculkan persoalan terkait keberadaan kesenian tradisi yang sering diselenggarakan di panggung prosenium. Tayangan media televisi hampir tidak pernah menyisakan waktu kosong sedikitpun, sebaliknya pertunjukan berbasis kerakyatan yang diselenggarakan secara live dianggap ketinggalan jaman dan tidak memberi keuntungan pasar. Persoalan tersebut merupakan "fenomena sosial" yang menarik untuk diteliti. Penelitian ini bertujuan mendeskripsikan faktor pendukung, menjelaskan penataan skenografi dan peranan di balik keberadaan pertunjukan ludruk Irama Budaya. Untuk menganalisa penelitian digunakan teori relevan melalui analogi Goffman ditunjang berbagai konsep skenografi. Penelitian dengan metode kualitatif dan pendekatan skenografi ini, lebih menitik-beratkan teknik pengumpulan data lewat observasi, wawancara, dan studi pustaka. Penelusuran faktor-faktor pendukung dan penataan tata artistik menghasil-kan asumsi tentang peranan skenografi di balik keberadaan pertunjukan ludruk Irama Budaya Surabaya
\end{abstract}

Kata Kunci: skenografi, pertunjukan, kesenian tradisi berbasis kerakyatan

\begin{abstract}
Satisfaction taste and aesthetic value obtained by the audience through interaction in performances often becomes an issue that leads to a decline in production activites. The las few decades, ludruk as a show of popular-based tradition, now seems to be deserted by spectators, and the fundamental problem when Irama Budaya shows as the only tobong ludruk that survives in Surabaya has not been able to attract the attention of the audience. The show, which was held live at the
\end{abstract}


Surabaya THR Ludruk Building, is now increasing hte burden of the problem when televesion media develops and increases very rapidly. Various entertainment shows based in the popular art industry, are now supported by artistic arrangements with technological sophistication, but also raises issues related to the existence of traditional arts that are often held on the prosenium stage. Television media broadcasts almost never leave the slightest amount of thime, otherwise populistbased performances held live are considered outdated and do not provide market benefits. This problem is interesting "social phenomenon' to study. This research aims to describe the supporting factors, explaining the scenography arrangement and the role behind the existence of the Irama Budaya ludruk show. To analyze the research the relevant theory is uesed through observation, interviews, and literature studies. The search for supporting factors and the arrangement of artistic arrangements resulted in assumptions about the role of the scenography behind the existence of the Irama Budaya Surabaya ludruk show.

Keywords: scenography, performances, traditional arts based on society

\section{PENDAHULUAN}

Seni pertunjukan merupakan bentuk karya seni yang mengutamakan segi "tontonan", dan senantiasa berkaitan erat dengan berbagai persoalan yang kompleks, terutama tentang perkembangan serta kelangsungan hidup maupun masa depannya sebagai komunitas seni komunal. Berbagai peristiwa dalam kehidupan seni pertunjukan dapat cepat berlalu setelah pementasannya mendapat sambutan dari para penonton yang memadati gedung ataupun arena pertunjukan. Namun penyelenggaraan kegiatan seni pertunjukan diberbagai kawasan sampai sekarang masih menyisakan banyak persoalan dalam mempertahankan keberadaan pertunjukan maupun komunitas keseniannya. Hal tersebut sebagaimana terjadi pada kehidupan komunitas ludruk Irama Budaya di Taman Hiburan Rakyat Surabaya atau yang lebih dikenal dengan sebutan "kompleks THR". Perkembangan dan kelangsungan hidup seni pertunjukan, pada saat sekarang sangat bergantung dengan kondisi lingkungan masyarakat sebagai pendukung utamanya, karena setiap adanya perubahan dalam lingkungan masyarakat tersebut, akan membawa pengaruh pula terhadap keberadaan komunitas di dalamnya.

$\begin{array}{ccr}\text { Kelompok ludruk } & \text { Irama } & \text { Budaya } \\ \text { meskipun dalam } & \text { keadaan } & \text { yang }\end{array}$ memprihatinkan, namun merupakan komunitas kesenian yang mampu bertahan hidup hingga sekarang, sehingga kelompok ini dapat merefleksikan persoalan-persoalan yang terkait dengan keberadaan pertunjukan pada berbagai komunitas kesenian tradisi berbasis kerakyatan. Menurut Purnomo (2015:264), bahwa kondisi sosial masyarakat kota Surabaya dapat berpengaruh terhadap perilaku penonton, dan secara tidak langsung hal tersebut juga berdampak pada setiap kegiatan pertunjukan yang diselenggarakan. Kondisi demikian menjadi tantangan yang sangat berat bagi kelompok ludruk Irama Budaya untuk mempertahankan keberadaan pertunjukan yang posisi hidup dan berkembangnya di tengah masyarakat kota Surabaya.

Pertunjukan ludruk Irama Budaya yang dipentaskan secara langsung (live) di Gedung 
Ludruk kompleks THR, merupakan bentuk kegiatan kreatif seni pertunjukan yang dilakukan lewat proses: penyutradaraan, pemeranan maupun penataan artistik. Interaksi penonton dalam kegiatan yang dilakukan secara visual maupun audio tersebut, sangat menentukan keberadaan pertunjukan Irama Budaya di atas panggung. Namun kepuasan atau nilai estetik yang didapatkan penonton melalui komunikasi seni, sering pula menjadi persoalan yang akhirnya berujung terhadap merosotnya berbagai aktivitas produksi pergelaran. Beberapa dekade terakhir, pertunjukan ludruk Irama Budaya yang diselenggarakan di Gedung Ludruk T H R tampak sepi penonton. Persoalan yang ironis ketika pertunjukan yang diselenggarakan hanya sebatas memenuhi rutinitas (periodik) kegiatan pentas belaka, sehingga sebagai satusatunya ludruk tobong yang masih hidup di Surabaya hingga sekarang ini, masih terus tertatih-tatih pertumbuhannya.

Pertunjukan ludruk Irama Budaya yang masih diselenggarakan secara live, kini bertambah beban permasalahanya ketika media televisi telah mengalami perkembangan dan peningkatan yang sangat pesat. Berbagai tayangan hiburan di media televisi yang berbasis industri seni popular, banyak memunculkan persoalan terkait keberadaan pertunjukan kesenian tradisi berbasis kerakyatan yang diselenggarakan di panggung prosenium. Pertunjukan di media televisi yang dirancang melalui panataan artistik telah didukung kecanggihan teknologi, dan tayangan acara hampir tidak pernah menyisakan waktu kosong sedikitpun. Sebaliknya kemasan pertunjukan kesenian berbasis kerakyatan, kini dianggap telah ketinggalan jaman dan tidak dapat memberi keuntungan "pasar", sehingga secara perlahan pendukungnyapun juga mulai ikut merosot. Hal tersebut merupakan "fenomena sosial" yang menarik sebagai subjek ataupun objek penelitian, dan terkait penggalian data, penelitian difokuskan melalui pendekatan skenografi pada pertunjukan ludruk Irama Budaya yang dipentaskan di atas panggung prosenium.

Skenografi dalam pertunjukan ludruk Irama Budaya yang diselengarakan di atas panggung prosenium, belum digarap secara serius untuk mendatangkan penonton. Menurut Dewi dan Koesoemadinata (2012:23), bahwa salahsatu faktor penting dalam kesuksesan drama...adalah desain artistik panggungnya yang sangat spektakuler dengan permainan komposisi warna, bentuk, furnitur, hingga multi media. Selama pertunjukan berlangsung, penonton selalu dapat berdecak kagum setiap kali desain panggung berganti menyesuaikan pergantian adegan. Penelitian ini dilakukan dengan cara menelusuri dan mencermati pertunjukan ludruk Irama Budaya yang diselenggarakan secara rutin di Gedung Ludruk kompleks THR Surabaya dengan berbagai alasan maupun pertimbangan:

1. Adanya korelasi perkembangan media televisi yang pesat dengan merosotnya produksi pergelaran ludruk tobong Irama Budaya, sehingga berdampak terhadap animo penonton sebagai muara pertunjukan.

2. Kelompok ludruk Irama Budaya dengan berbagai persoalan yang menghimpit, kondisi yang disandang dan dijalaninya, justru masih sanggup bertahan hidup, 
bahkan memiliki semangat menyelenggarakan pertunjukan yang kini kurang diminati penonton.

3. Pertunjukan berbasis kerakyatan terus menghadapi persaingan dengan industri hiburan berbasis seni popular, sehingga berpengaruh terhadap keberadaannya

4. Penelitian tentang kesenian tradisi berbasis kerakyatan yang difokuskan melalui tata artistik (skenografi) masih jarang dilakukan secara mendalam, khususnya terkait keberadaan pertunjukan secara live di atas panggung prosenium.

Skenografi menjadi tumpuan utama untuk mendukung keberadaan pertunjukan ludruk Irama Budaya Surabaya, sehingga permasalahan dapat dirumuskan 1) apakah yang menjadi daya dukung pertunjukan ludruk Irama Budaya Surabaya? 2) bagaimana penataan skenografi pertunjukan ludruk Irama Budaya Surabaya yang diselenggarakan di atas panggung prosenium? dan 3) bagaimana peranan skenografi di balik keberadaan pertunjukan ludruk Irama Budaya Surabaya?

\section{METODE}

Keberadaan pertunjukan ludruk Irama Budaya di Gedung Ludruk kompleks THR Surabaya, merupakan fenomena sosial yang terjadi pada kehidupan seni pertunjukan. Untuk memahami fenomena digunakan skenografi sebagai unsur utama pementasan untuk pendekatan atau strategi penelitian. Skenografi juga digunakan untuk mendalami fenomena di balik keberadaan pertunjukan berkaitan dengan kondisi audiens.

Dalam memperoleh data di lapangan, penelitian ini menggunakan: 1) observasi untuk mengamati beberapa partisipan maupun memahami fenomena yang berhubungan secara langsung maupun tidak langsung terhadap pertunjukan, serta memiliki hubungan dengan objek maupun subjek penelitian; 2) wawancara terhadap informan untuk me-ngumpulkan data yang merujuk fokus atau rumusan penelitian; 3) Studi kepustakaan dan dokomen untuk mendapatkan data-data referensi yang berhubungan perjalanan kelompok ludruk Irama Budaya ketika awal-mula didirikan.

Untuk menemukan hasil penelitian tentang keberadaan pertunjukan ludruk Irama Budaya, kegiatan yang dilakukan adalah mengklasifikasikan hingga memberi makna terhadap hasil dari pengamatan, wawancara, pencatatan, dan perekaman yang telah diperoleh lewat pengumpulan data dari berbagai informasi mengenai fenomenafenomena yang terjadi sebagai objek penelitian. Menurut Emzir (2012:86), bahwa tugas analisis menafsirkan dan membuat makna materi-materi yang telah dikumpulkan dapat muncul sebagai tugas monumental ketika seseorang untuk pertama kalinya terlibat dalam proyek penelitian

Menurut Lincoln dan Guba, paling sedikit terdapat empat standar atau criteria utama untuk menjamin keabsahan data hasil penelitian kualitatif, yaitu: a) standar kredibilitas, b) standar transferabilitas, c) standar dependabilitas, dan d) standar konfirmabilitas (Bungin, 2012). Dalam penelitian ini, keabsahan data lebih difokuskan terhadap standar kredibilitas. Hal ini dimaksudkan agar data dari hasil penelitian kualitatif memiliki tingkat kepercayaan yang tinggi sesuai fakta di lapangan, yaitu informasi 
yang digali melalui subjek atau partisipan yang diteliti.

$$
\text { Dalam penelitian berkaitan }
$$
keberadaan pertunjukan ludruk Irama Budaya, validasi data dilakukan memalui triangulasi, hal tersebut untuk mengutamakan efektivitas proses dan hasil yang diinginkan. Triangulasi dilakukan dengan cara menguji apakah proses dan hasil metode yang digunakan sudah berjalan baik. Proses triangulasi dilakukan terus menerus sepanjang proses mengumpulkan data maupun analisis data, sampai suatu saat peneliti merasa yakin bahwa sudah tidak ada lagi adanya perbedaanperbedaan, dan tidak ada lagi yang perlu dikonfirmasikan kepada para informan.

\section{HASIL DAN PEMBAHASAN}

Faktor Pendukung Pertunjukan Ludruk Irama Budaya

Pertunjukan ludruk Irama Budaya yang diselenggarakan secara live di Gedung Ludruk kompleks $\mathrm{T}$ H R, didukung oleh berbagai aspek yang langsung berhubungan dengan kegiatan di atas panggung: 1) penyutradaraan; 2) pemeranan; dan 3) penataan artistik pertunjukan. Sedangkan aspek pendukung yang tidak langsung berhubungan dengan kegiatan di atas panggung adalah penonton (audien) dan pengelolaan (manajemen) komunitas kesenian. Namun di dalam penelitian ini aspek pendukung pertunjukan ludruk Irama Budaya tersebut difokuskan pada persoalan tata artistik. Skenografi yang sering juga disebut penataan artistik, bidang ini membawahi bagian Set-Dekor-Properti, Tata Busana, Tata Rias Wajah dan Rambut, serta Tata Cahaya. Perlu ditekankan bahwa skenografi merupakan bagian yang tak terpisahkan dari sebuah pertunjukan teater (Riantiarno, 2011:XI). Sehingga pengumpulan data dalam penelitian ini akan berkaitan dengan berbagai visual atau gambar bentuk artistik secara keseluruhan yang meliputi:

\section{Latar Peristiwa (Setting)-Dekorasi (Scenery)}

Setting ataupun dekorasi (scenery) merupakan bentuk tata artistik yang secara visual dapat menggambarkan: 1) suasana atau keadaan suatu peristiwa; 2) dimana peristiwa tersebut terjadi; dan 3) kapan terjadinya peristiwa tersebut, sehingga setting ataupun dekorasi sangat berkaitan langsung dengan struktur pertunjukan di dalam kesenian tradisi khususnya ludruk Irama Budaya. Keberadaan setting ataupun dekorasi dapat menjadi tumpuan utama yang harus hadir sebagai pendukung penting pada sebuah pertunjukan.

Dalam pertunjukan ludruk Irama Budaya, yang dimaksud setting ataupun dekorasi adalah gambar sebuah pemandangan yang biasanya sering disebut dengan istilah "kelir". Kelir tersebut merupakan pemandangan yang divisual-kan atau dilukis pada selembar kain seluas dinding bagian belakang (backdrop) panggung pertunjukan. Penempatan kelir dapat digulung ke atas, dan untuk memainkannya akan diturunkan kembali sesuai dengan lakon yang ditampil-kan. Untuk lebih menghidupkan suasana, di depan kerir sering ditambahkan perlengkapan pendukung artistik lainnya yang disesuaikan dengan kebutuhan adegan di dalam pertunjukan, misalnya bebatuan besar, tanaman pohon, pagar bambu atau kayu, gapura dan sebagainya.

Visual kelir di dalam pertunjukan ludruk Irama Budayat ersebut, tidak memiliki filosofi 
apapun terkait cerita/ lakon yang dipentaskan.

Gambar kelir adalah mewakili setting atau tempat kejadian peristiwa, sehingga visualnya hanya mencerminkan bahwa kejadian tersebut setting-nya tentang kondisi di daerah pedesaan, maka suasananya juga harus mengikuti keadaan di desa, dan sangat tidak mungkin akan diturunkan kelir yang suasananya tentang kondisi di kota, istilah di dalam wilayah teater disebut dengan jumping.

Berkaitan dengan penataan artistik, setting itu harus mengacu terhadap cerita/ lakon yang dipentaskan, kalau misal pertu adegan laut atau adegan sungai, maka dapat digunakan properti tambahan. Jika ada semacam kelir desa dapat ditambah dengan properti yang menggambarkan sungai, maka perlu dibikin properti yang menggambarkan tentang suasana kali. Misalnya cerita tentang bengawan solo yang harus ada properti tambahannya yang kalau dilihat secara artistik hal itu memang harus menggambarkan sungai.

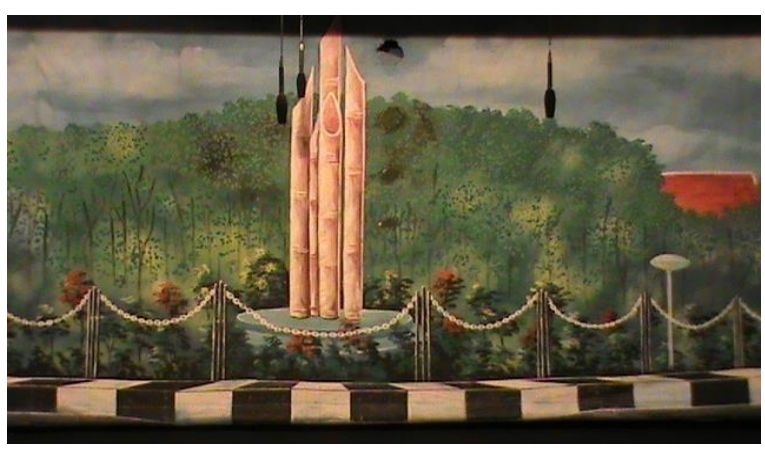

Gambar 1. Jalan Bambu Runcing, menggambarkar taman yang ada bambu runcingnya dengan dikeliling: tanaman (sumber: Henimen, 2017)

Dalam pertunjukan ludruk Irama Budaya, gambar kelir ini sering digunakan sewaktu acara dagelan atau lawakan dan monosuko. Pada ranah penonton, kelir bergambar jalan bambu runcing digunakan sebagai penanda dagelan atau lawakan segera tampil. Struktur pertunjukan itu sangat ditaati dalam komunitas ludruk, akhirnya menjadi pakem di dalam sebuah pertunjukan, bahkan struktur pertunjukan tersebut semacam harga mati dalam melakonkan pementasan ludruk, walaupun tidak ada konvensi (perjanjian/kesepakatan).

Kelir menjadi setting atau dekorasi utama untuk menggambarkan sebuah peristiwa dalam struktur pertunjukan ludruk Irama Budaya, sehingga muncul komunikasi yang memiliki nilai estetik melalui visual artistik di atas stage. Kelompok ludruk tobong Irama Budaya dalam pementasannya memiliki 9 (Sembilan) gulung kelir yang telah terpasang di atas stage pertunjukan.

\section{Tata Busana (Costume)}

Tata busana merupakan bagian tata artistik yang digunakan para pemain selama pertunjukan ludruk Irama Budaya berlangsung. Tata busana berfungsi untuk menghidupkan karakter tokoh yang sedang diperankan para pemain, dan di dalam rangkaian atau struktur pertunjukan ludruk Irama Budaya ada beberapa jenis tata busana yang selalu dipergunakan pada setiap penampilan-nya, yaitu : 1) tata busana yang digunakan pengreman (penari Ngremo); 2) tata busana yang digunakan para bedhayan atau ceklekan; 3) tata busana yang digunakan para dagelan (pelawak) dan monosuko; serta 4) tata busana yang digunakan untuk para tokoh di dalam lakon yang akan dipentaskan. Menurut Supriyanto (2018:10) bahwa tata busana (kostum) menggambarkan kehidupan rakyat sehari-hari yang amat sederhana. Hal itu amat menonjol pada tata kostum pelawak yang sering berperan sebagai pembantu rumah 
tangga dengan mengenakan busana sehari-hari (topi/kopiah, busana apa adanya, dan kadangkadang bersarung) serta tat arias yang sederhana pula.

\section{Tata Rias (Make-Up)}

Tata rias merupakan bagian dari tata artistik yang fungsinya sama dengan tata busana yaitu digunakan untuk dapat menghidupkan berbagai karakter tokoh yang sedang diperankan oleh para pemain di dalam pertunjukan, sehingga sering digunakan istilah "tata rias-busana atau tata rias dan busana". Dalam struktur pertunjukan ludruk Irama Budaya, tata rias tersebut selalu dikaitkan dengan hasil "riasan" yang mempertimbangkan: 1) tokoh ataupun adegan yang diperankan; 2) bentuk wajah; 3) bahan rias yang digunakan; 4) baju yang dikenakan; dan 5) tata panggung. Menurut Hamzah (2007:39), bahwa tata busana dan tata rias adalah gambaran watak/ karakterisasi seseorang. Kostum maupun make-up bisa membantu seseorang pemeran meyakinkan penonton tentang peran yang dimainkannya.

\section{Tata Cahaya (Lighting)}

Tata Cahaya (lighting) atau pencahayaan menjadi bagian tata artistik yang dapat menerangi berbagai bagian panggung maupun adegan di dalam sebuah pertunjukan. Pencahayaan menjadi sarana penunjang pada saat pementasan yang berfungsi untuk memberikan efek-cahaya selain fungsi utamanya sebagai penerangan objek panggung. Dalam pertunjukan tradisi berbasis kerakyatan pencahayaan biasanya menjadi bagian tata artistik yang kurang diperhitungkan keberadaannya. Dalam setiap pementasan, pencahayaan juga sering hadir apa adanya dan hanya sekedar memberikan penerangan pada panggung maupun adeganadegan cerita dalam pertunjukan.

\section{Tata Suara (Audio Design)}

Tata Suara (Audio Design) merupakan bagian tata artistik yang berkaitan dengan penataan bunyi atau suara, sehingga untuk merasakan akan melibatkan indera pendengaran. Dalam pertunjukan ludruk Irama Budaya, Tata suara terbagi menjadi 2 (dua) bagian: 1) berkaitan dengan iringan musik yang menggunakan peralatan gamelan; 2) berkaitan dengan suara atau dialog para pemain di atas panggung. Untuk mendukung kedua bagian tersebut, diperlukan peralatan yang disebut "sound system". Sound system kini menjadi peralatan utama yang tidak terpisahkan dalam pertunjukan sebagai alat yang berfungsi menata ataupun mengatur suara sehingga bisa didengarkan semua penonton selama pertunjukan ludruk berlangsung.

\section{Perlengkapan (Property)}

Perlengkapan merupakan bagian tata artistik yang berkaitan dengan penataan barang atau benda sebagai pendukung pertunjukan. Dalam pertunjukan ludruk Irama Budaya, perlengkapan (property) meliputi barang yang berada di atas stage sebagai set properti (asbak, vas bunga, taplak, makanan kecil dsb) maupun barang yang dibawa pemain sebagai hand property (pistol, kipas, bolpoin, pedang, pisau dan sebagainya), sehingga properti dalam hal ini merupakan pelengkap dari set properti.

\section{Penataan Artistik dalam Pertunjukan Ludruk Irama Budaya}




\section{Struktur Panggung Pertunjukan Ludruk Irama Budaya}

Struktur panggung proseniun pertunjukan ludruk Irama Budaya, sama seperti struktur panggung prosenium pada umumnya. Struktur panggung prosenium mulai dari bagian panggung utama yang digunakan para pemain lakon, bagian-bagian penunjang panggung yang digunakan para penonton (audiens) maupun para pemain, sampai kepada fungsifungsi perangkat yang terdapat dalam panggung prosenium pertunjukan ludruk Irama Budaya.

Untuk mengetahui struktur panggung prosenium Gedung Ludruk kompleks T H R Surabaya yang digunakan sebagai penyelenggaraan pertunjukan ludruk Irama Budaya, dapat dibagi menjadi tiga bagian tempat utama, yaitu: 1) area auditorium;2) area panggung utama; dan 3) area panggung belakang (ruang rias dan ruang tunggu para pemain). Area panggung utama merupakan daerah yang digunakan oleh para pemain untuk berakting sesuai dengan lakon yang dipentaskan. Panggung utama pertunjukan ludruk Irama Budaya terdiri dari berbagai perangkat sebagai pelengkap maupun penunjang dari panggung prosenium, seperti: 1) bingkai panggung (proscenium); sebenk (wing flats); 3) pintu samping (wings); 4) kelir belakang (cyclorama/ backdrop); 5) kelir depan (scerm); 6) kain plisir(border); 7) gantungan lampu (lighting battens) area panggung; 8) tempat gamelan (pit orchestra); dan 9) panggung tambahan (apron), untuk lebih jelasnya dapat dilihat melalui gambar di bawah ini:

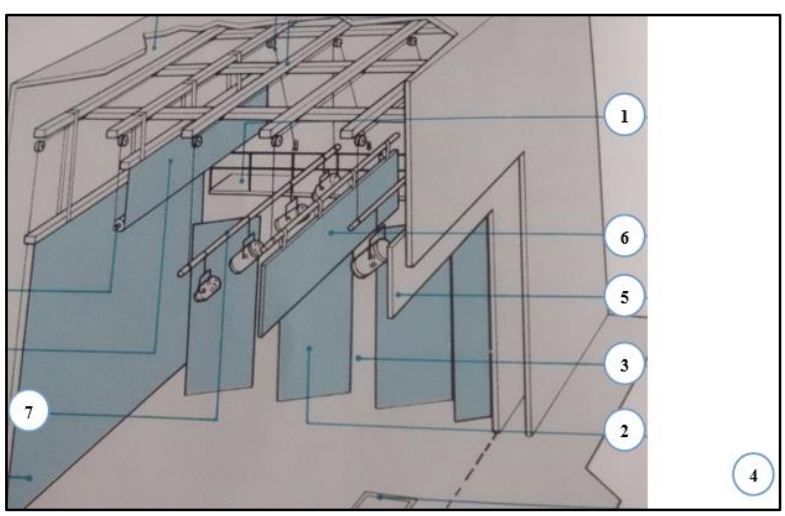

Gambar 2 Struktur Panggung yang digunakan untuk pertunjukan Ludruk Irama Budaya Surabaya (repro. dari Stagecraff, Trevor R.G 2017)

Area panggung belakang merupakan perangkat penunjang panggung prosenium yang terbagi menjadi dua ruangan: 1) ruang rias atau ruang ganti para pemain; dan 2) ruang tunggu para pemain yang antri menunggu giliran tampil pada pementasan. Ruang tunggu para pemain selain berfungsi sebagai tempat menunggu tampil di panggung, berfungsi pula sebagai lokasi santai, mengobrol, makan, minum, bahkan digunakan untuk mengkoordinasikan lakon yang akan ditampilkan oleh sutradara. Ruang tunggu para pemain ini biasanya sering difungsikan juga sebagai tempat diskusi bersama tentang masalah - masalah yang berkaitan dengan pertunjukan maupun perkembangan ludruk hingga dini hari.

\section{Penataan Artistik Panggung Prosenium Ludruk Irama Budaya}

Penataan artistik di atas panggung prosenium menjadi persoalan penting dan tidak dapat diabaikan dalam pertunjukan ludruk. Perbedaan panggung prosenium pertunjukan ludruk Irama Budaya dengan panggung prosenium lainnya terletak area backdrop, penempatan set-dekorasi (scenery) 
maupun spesifikasi pencahayaannya (lighting). Struktur bentuk panggung prosenium pertunjukan ludruk menjadi hal yang sangat menarik untuk ditelusuri dan dikaji. Menurut Padmodarmaya (1988:60),pentas yang menggunakan bentuk prosenium, biasanya juga menggunakan ketinggian atau panggung, sehingga lebih tepat kalau dikatakan sebagai panggung prosenium. Hubungan antara panggung dengan auditorium dipisahkan atau dibatasi dengan dinding dan lubang prosenium. Sedangkan sisi atau tepi lubang prosenium yang berupa garis lengkung atau garis lurus dapat kita sebut dengan pelengkung proscenium (proscenium arch).

Strategi penempatan set - dekorasi (scenery) atau set - properti pada panggung proseniun pertunjukan ludruk Irama Budaya sering mengikuti visual kelir yang akan digunakan dan lakon yang dipentaskan, sehingga pemasanganya- pun senantiasa berubah-ubah sesuai dengan pertunjukannnya.

Persoalan pemasangan setting/kelir juga sangat berbeda dengan ketika penampilan tersebut diadakan di dalam studio rekaman (seperti ludruk R R I Surabaya), maka penonton harus mengimajinasikan bahwa mereka berada di suatu tempat kejadian. Kalau pertunjukan ludruk tobong tersebut sudah dibantu dengan adanya kelir yang dapat mewakili setting, sehingga untuk suasananya penonton juga tidak perlu dijelaskan lagi karena sudah bersifat langsung (live).

Pencahayaan sebagai bagian tata artistik (scenografy) di panggung prosenium, sebenarnya dapat memberikan penerangan di area panggung maupun objek pemeranan yang dilakonkan di dalam pertunjukan ludruk. Namun untuk meng-hadirkan suasana lakon/ cerita di dalam setiap pertunjukan ludruk Irama Budaya hal tersebut senantiasa berujung pada adanya keterbatasan sumber daya yang dimiliki oleh pengelolanya, baik secara sumber daya barang/ benda maupun sumber daya manusianya. Sebenarnya secara ideal pencahayaan tersebut sudah harus dapat mengeksekusi suasana yang akan dihadirkan atau ditampilkan dalam lakon/cerita sebuah pertunjukan.

Penataan artistik pada pertunjukan ludruk Irama Budaya yang dipentaskan secara rutin dan live di dalam Gedung Ludruk $\mathrm{T}$ H R Surabaya, senantiasa mengikuti unsur-unsur yang terdapat di atas panggung prosenium. Tata panggung prosenium tersebut memiliki berbagai prinsip dasar dan struktur bentuk, bahkan berbagai istilah yang sudah baku sebagai sebuah konvensi secara internasional. Hal tersebut semestinya justru dapat menjadikan kegiatan produksi pementasan maupun penataan artistik khususnya, harus senantiasa dapat berkembang dan mengikuti setiap perubahan perilaku atau selera penonton sebagai masyarakat pendukungnya. Namun pada waktu sekarang, para penonton tersebut sangat sulit untuk ditebak ataupun diikuti seleranya di dalam memilih suatu pertunjukan, apalagi untuk pementasan ludruk Irama Budaya yang merupakan salah satu pertunjukan dengan memiliki basis kerakyatan. Karena pertunjukan ludruk tersebut kini harus mampu bersaing pula dengan berbagai pertunjukan sebagai multi media yang memiliki basis "seni popular".

\section{Peranan Tata Artistik dalam Pertunjukan Ludruk Irama Budaya}


Dalam pertunjukan ludruk Irama budaya, kehadiran penonton masih merupakan persoalan utama dan menjadi barang langka yang mahal. Menurut Harymawan (1988:193), bpenonton dalam pertunjukan adalah orangorang yang mereka secara sengaja menginginkan untuk mendapatkan rasa kepuasan dari hasil menonton. Mereka pergi menonton dengan maksud yang pertama-tama memang untuk memperoleh kepuasan rasa, lalu kebutuhan dan keinginannya juga dapat terpenuhi. Hal tersebut dengan kata lain bahwa penonton itu ingin mendapatkan suatu kepuasan batin sebagai oleh-oleh yang menarik untuk dibawa pulang tanpa terbebani oleh hal-hal yang lainnya. Menurut Purnomo (2015:248), penonton pada saat sekarang merupakan penonton yang telah diasuh dan dibesarkan oleh kejayaan media televisi. Penonton juga rentan dipengaruhi kondisi kondisi sosial maupun ekonomi di lingkungannya, artinya penonton tersebut dapat memiliki suatu sikap yang dipengaruhi oleh berbagai faktor lingkungannya.

Berbagai faktor sosial dalam masyarakat pada saat ini dapat menjadikan pertunjukan ludruk Irama Budaya sepi penonton, sehingga akhirnya menjadi pemicu berbagai persoalan dalam pementasan nanti ke depannya. Semakin lama pertunjukan ludruk Irama Budaya terus menghadapi persaingan hiburan dari luar yang pada saat sekarang sudah mulai berkembang sangat pesat. Awal persaingan tersebut dapat muncul dari gedung-gedung bioskop. Namun sekarang ditambah dengan hadirnya media televisi yang telah disertai dengan semakin banyaknya stasiun televisi dengan bermacam acara yang dapat ditayangkan di layar kaca.
Penonton dan pertunjukan ludruk Irama Budaya merupakan dua komponen yang senantiasa berinteraksi untuk mendapatkan keberadaan masing-masing. Namun perkembangan pertunjukan saat sekarang banyak yang dikomodifikasikan melalui media televisi, dan hal tersebut dapat membawa pengaruh ataupun dampakterhadap pola pertunjukan ludruk tobong Irama Budaya maupun perilaku penontonnya. Pengaruh pengaruh tersebut akhirnya memicu pula munculnya bentuk perubahan yang secara lambat-laun juga berakibat pada pertunjukan ludruk Irama Budaya. Berbagai pertunjukan atau hiburan yang dipentaskan di layar kaca media televisi dapat melahirkan bentuk perubahan yang terjadi pada pola (structure) penampilan maupun tempat pertunjukannya (stage).

Kesuksesan sebuah pertunjukan, salah satunya akan ditentukan oleh jumlah penonton yang menyaksikan, termasuk dalam setiap pertunjukan ludruk Irama Budaya yang pada saat sekarang ini penontonnya sudah menjadi barang yang langka. Bahkan keberadaan pertunjukan pada saat sekarangpun dapat ditentukan berbagai perilaku "massa" sebagai penonton, dan penonton sebagai faktor pendukung yang utama di dalam pertunjukan ludruk Irama Budaya dapat digunakan sebagai tolok-ukur sukses atau keberhasilannya sebuah pementasan. Merosotnya pertunjukan ludruk Irama Budaya di Gedung Ludruk kompleks THR pada saat sekarang ini dikarenakan pertunjukan tersebut tidak dapat lagi menarik minat penonton, dan jika diibaratkan pentas itu sampai di liang semut sekalipun, kalau memang pertunjukannya menarik, maka tetap akan diburu oleh para penonton (audiens). 
Sehingga untuk memahami selera penonton, maka dilakukan pendekatan melalui bidang tata artistik sebagai pendukung utama dalam pertunjukan ludruk Irama Budaya yang diselenggarakan secara live di Gedung Ludruk kompleks THR Surabaya.

Tata Artistik yang dibangun berdasarkan unsur - unsur: titik, garis, bidang, ruang, jarak, arah, irama, intensitas, warna, maupun dimensi pada panggung prosenium pertunjukan ludruk Irama Budaya, hasilnya kurang maksimal karena kondisi pemain yang usianya sudah semakin menua dan kurang adanya regenerasi. Sehingga hasil visual secara total dapat memunculkan banyak persoalan terkait dengan tata artistik panggung prosenium pertunjukan ludruk. Banyaknya pemain senior yang sudah menua menjadikan penonton dari kalangan generasi muda juga kurang tertarik terhadap pertunjukan ludruk Irama budaya, akhirnya penontonpun kini banyak yang berasal atau didominasi oleh kalangan orang tua.

Tata artistik secara komprehensif dapat memberikan kepuasan penonton melalui visual pementasan, dalam pertunjukan ludruk Irama Budaya banyak yang terabaikan penataannya. Penataan artistik bisa dikerjakan melalui berbagai bentuk artistik seperti: 1) latar kejadian peristiwa (setting) - dokorasi (scenery); 2) tata busana (costum); 3) tata rias (make-up); 4) pencahayaan (lighting); 5) tata suara (audio design ); dan perlengkapan (property), merupakan kegiatan yang dapat memberikan solusi untuk menarik minat para penonton menyaksikan pementasan, namun hal tersebut hingga sekarang juga kurang mendapatkan perhatian/ respon dengan secara serius dari para pengelola kelompok ludruk Irama Budaya yang di-selenggarakan secara rutin dan live di Gedung Ludruk Kompleks T H R Surabaya.

Penonton pertunjukan ludruk Irama Budaya yang semakin merosot, perlu mendapatkan perhatian yang serius lewat penataan artistik panggung prosenium untuk menghasilkan visual yang menarik (estetik) dalam pementasan ludruk. Tata artistik pertunjukan ludruk Irama Budaya yang kurang mendapatkan perhatian dari para pengelolanya secara perlahan-lahan akan membawa "citra" yang kurang baik dan pemahaman yang salah, sehingga setiap pertunjukan ludruk Irama Budaya yang diselenggarakan secara rutin dan live di Gedung Ludruk T H R Surabaya secara visual senantiasa kurang berkembang serta bersifat staknasi.

\section{KESIMPULAN}

Kesuksesan sebuah pertunjukan, salahsatunya ditentukan jumlah penonton yang menyaksikan, termasuk di dalam setiap pertunjukan ludruk yang sekarang penontonnya sudah menjadi barang yang langka. Merosotnya pertunjukan ludruk Irama Budaya di Gedung Ludruk T H R dikarenakan pertunjukan tersebut tidak dapat lagi menarik minat penonton, hal tersebut dapat dikarenakan kurang berfungsinya skenografi sebagai pendukung utama dalam setiap pertunjukan. Penataan artistik tidak dilakukan dengan cara yang benar dan serius. sehingga secara visual maupun audio dapat berdampak terhadap keberadaan pertunjukan ludruk Irama Budaya.Skenografi memiliki peranan menghadir-kan nilai estetik sebagai salah satu arti dan makna yang dimiliki oleh tanda - tanda yang disajikan di atas panggung pertunjukan. 


\section{DAFTAR PUSTAKA}

Bungin, Burhan. 2012, Analisis Data

Penelitian Kualitatif: Pemahaman

Filosofis dan Metodologis ke

Arah Penguasaan Model Aplikasi.

Jakarta: Rajawali Pers.

Dewi, Citra Smara.dan Koesoemadinata,

Fabianus Hiapianto. 2012. Menjadi

Skenografi. Solo: Metagraf.

Emzir. 2012, Analisis Data: Metodologi

Penelitian Kualitatif. Jakarta: Rajawali

Pers.

Hamzah, A. Nawir. 2007. Sutradara Drama

Panggung dan Televisi, Jakarta: Win

Communications.

Harymawan, R.M.A., 1988, Dramaturgi.

Bandung: $\mathrm{R}$ o s d a.

Jazuli, M., 2014. Sosiologi Seni:

Pengantardan Model Studi Seni.

Yogyakarta: Grahallmu.

Padmodarmaya, Pramana. 1988, Tatadan

Teknik Pentas. Jakarta: Balai Pustaka.

Purnomo, Heny.2 01 5. “Aneka Ria Srimulat:

Kajian Seni Populer di Kompleks Taman

Hiburan Rakyat Surabaya". Tesis

Magister, Universiyas Negeri Surabaya.

Riantiarno, N. 2011, Kitab Teater: Tanya

Jawab Seputar Seni Pertunjukan. Jakarta:

Grasindo.

Supriyanto, Henri. 2018, Ludruk dalam

Pusaran Zaman. Surabaya: Dinas

Pendidikan dan Kebudayaan Provinsi

Jawa Timur 